\title{
SHOULD HUMAN HISTORY GIVE US HOPE?
}

\author{
Pouwel Slurink \\ Nijmegen, The Netherlands \\ P.Slurink@kpnplanet.nl
}

A Review of the Book

Humankind, a Hopeful History

By Rutger Bregman, 2020.

Bloomsbury Publishing, London, UK, 496 pages.

ISBN 9781408898932 (Hardback Edition, $£$ 14.00, Paperback Edition, $£$ 8.99)

Rutger Bregman (1988) is an engaged historian and a prolific writer. In the Netherlands he became known nationwide for his socially critical articles and a book, pleading for a basic income. In his latest book, Humankind: a hopeful history he deals with scientists which are too misanthropic. According to Bregman, science has often judged man too harshly - which works as a self-fulfilling prophecy. This negativity already started in the Enlightenment, according to Bregman: philosophers like Adam Smith and David Hume believed in the goodness of man, but Adam Smith, particularly, did not want to rely on it in trade and politics. During the industrialization some scientists gradually became more and more pessimistic, especially since the Second World War. Scientists such as Stanley Milgram (with his electroshock experiments), Philip Zimbardo (known from the Stanford prison experiment) and Richard Dawkins (author of The Selfish Gene) have proclaimed that humans are above all selfish, opportunistic and greedy. According to Bregman, this image of man reflects and reinforces our predatory capitalism based on distrust, greed and exploitation. In the end, we get the world which we expect.

The solution, according to Bregman, is simple: we must reverse the self-fulfilling prophecy, replace the misanthropic 'Golem effect' with the optimistic 'Pygmalion effect'. History proves time and again that people are capable of incredible good deeds. Evolutionally, we are the product of self-domestication and actually gentle 'puppy' primates, a merry puppy, as Bregman calls us. Most people are good: this is actually the title of the original Dutch version of the book. We are 
definitely better than all those negative scientists think. If we continue to believe in the power of ideals, we can pull ourselves out of the (self-created) capitalist swamp by our own hair, fight inequality, introduce basic income and make the world beautiful again.

To underpin his belief in the goodness of man, Bregman gives many edifying examples, such as beautiful stories about collaboration from behavioral biology and history. He tries to disprove all kinds of psychological and anthropological research by concentrating on its weaknesses, often using critical open peer commentaries from other scientists selectively. In this way, he tries to rewrite mankind's history.

If you disagree with Bregman this procedure is sometimes counterproductive. You quickly notice that he only sketches one side of the story and that his knowledge is very fragmentary in many areas. Particularly disturbing is his poor understanding of evolution, the way in which he repeats and thickens clichés about behavioral biology and the arbitrariness with which he selectively picks up data from anthropology and paleontology to sketch a very incomplete and improbable version of human evolution.

The great cliché about the behavioral biology of the twentieth century is that it mainly preached a pitch-black genetic determinism. Unfortunately, this myth has been spread by some behavioral biologists themselves. Frans de Waal, for instance, repeatedly presents Dawkins' The Selfish Gene as a cynical, genetically deterministic treatise. The fact is that the literature that Dawkins popularized in his book points to the existence of much social and altruistic behavior in nature and in man. The big question was whether this behavior was the product of selection at the level of individuals, relatives, groups or even genes. Dawkins rejects the idea that altruism is beneficial to the species. It is also rarely beneficial to the group. According to Dawkins, it is especially beneficial to collaborating individuals or to the genes they share. This is an evolutionary explanation of altruism, not a denial of it. An altruistic disposition can be detrimental to an individual, but beneficial to relatives. Bregman does not know or understand the whole discussion and blindly copies De Waal's criticism. In this way he spreads these misunderstandings even further and, ironically enough, receives De Waal's praise on the cover text. It would have been fairer and more interesting to see whether there are other evolutionary biologists who interpret the literature differently and to look whether Dawkins himself contributed to the misunderstandings.

In this way, by defusing some gloomy scientific claims (and some facts), Bregman can paint a rosier picture of evolution, especially of mankind. He presents the lives of the original huntergatherers, our distant ancestors, as a fairy tale. Of course, hunter-gatherers have fewer classes and positions than in sedentary societies after the agricultural revolution. But hunter-gatherers also have to work together, despite conflicts or interests, which results in a variety of behavioral strategies. That means that even among them the relatively nice ones have to deal with assholes, profiteers, sloths and thieves.

Bregman uses work by Christopher Boehm to show that hunter-gatherers are egalitarian, but ignores his book about the death penalty among preindustrial and prehistoric peoples (Boehm, 2012). Boehm shows that hunter-gatherers also quarrel a lot about dedication, loyalty, abuse, theft and parasitism. Morality has partly evolved to suppress all kinds of selfish traits. That process is never finished: we still have to force people to do the right thing by making sure that crime does not pay. Most people are only nice with constant vigilance, education and social control. Richard Alexander (1987) called this enforced, controlled cooperation 'indirect reciprocal altruism'. Boehm explains morality and moralism through millennia of social selection, selection by peers. Spontaneous helpfulness and heroism in the interest of the group did not come to us spontaneously, but needed constant enforcement, stimulation, cultivation. 
Bregman does not seem to realize that without scarcity and struggle there is no selection and evolution. Morality seems to have blossomed with him just like that, like a beautiful flower that doesn't need to be pollinated. He is right to write about the self-domestication of mankind, but he also pretends that it happens by itself. He does not answer the question which selection factors have played a role.

Apparently Bregman believes that we are already started as a Homo puppy. Paranoid leaders and scientists in white coats have convinced us that we are no good. Bregman, however, makes grateful use of scientists who criticize the carelessness and hypochondria of their colleagues. For example, anthropologist Raymond Dart was too pessimistic when he thought that the Australopithecus africanus he discovered was a bloodthirsty predator. Despite much criticism within the paleontology of these pessimistic claims, later humanoids do appear to have predatory and sometimes cannibalistic traits. Australopithecus was still troubled by birds of prey and big cats, but later humanoids were better armed and stood at the top of the food pyramid. They suffered more from each other than from other predators and sometimes got involved in tribal warfare. According to Darwin and some modern researchers, groups of relatively heroic and loyal fighters had the advantage. Once again we see how virtues can be the product of selection.

Bregman, however, 'refutes' all kinds of claims about violence among natural peoples and violence in prehistory by consistently only transcribing criticism within scientific discussions. In doing so, he ignores clues and evidence that have withstood the test of criticism. The scratches on the skull of Bodo (a kind of Heidelberg man), for example, have been studied by Tim White with an electron microscope and seem to have been applied with a fist axe. The wound in the leg of one of the Neanderthals from the Iraqi cave near Shanidar seems to have been caused by a javelin, possibly from a sapiens. Genetic research shows that both northern Europeans and northern Indians carry genes from nomadic shepherds from the Asian steppes. These Yamnaya, as they are called, entered Europe 5000 years ago and caused unrest in the lives of the then Europeans. In Poland, a mass grave was found in which everyone was murdered with a blow to the skull. In Spain, $\mathrm{Y}$ chromosomes come mainly from the invasive nomads.

All in all, Bregman's claim that we are a 'Homo puppy' by nature is not realistic. He is not very convincing either in his attempts to neglect the dark side of man, and to explain and 'massage' it away, so to speak. According to him, war crimes and terrorism are only due to the limited scope of empathy, the comradery of warriors, the xenophobic side effect of the cuddly hormone oxytocin and a training aimed at suppressing empathy: evolutionary and cultural mishaps, so to speak. Of course, it is mainly those in power who are wrong: power corrupts and paralyzes empathy and the feeling of shame. Time and again it is narcissistic and sociopathic rulers who manipulate and bring ruin to all. How these kinds of rulers come to power remains a mystery...

All in all, Bregman shops selectively in science to undermine her. He selectively picks opinions from scientific discussions to create a one-sided fairy tale. One moment science is to blame for the capitalist nightmare, the next it is indispensable to claim that cooperation in nature is more important than struggle and competition. The problem is that his image of evolution, evolutionary biology and paleontology remains too fragmentary. It is true that behavioral biologists have started to emphasize cooperation, but cooperation is just as much a weapon in the struggle for existence as open competition. The idea that humans are a successful species as a result of collaboration is as old as Darwin. However, no biologist can seriously defend that collaboration is more important than struggle and competition, for the simple reason that collaboration is a way to compete, too. 


\section{ABOUT THE AUTHOR}

DR. POUWEL SLURINK (PH.D.) is a philosopher of science giving courses in the philosophy of science, the philosophy of mind, ethics, evolutionary psychology, and paleoanthropology. He wrote a Dutch book on evolutionary philosophy, Aap zoekt zin, 2014, and many papers.

\section{REFERENCES}

Alexander, R. (1987). The Biology of Moral Systems. New York: Aldine de Gruyter. DOI

Boehm, C. (2012). Moral Origins. The Evolution of Virtue, Altruism, and Shame. New York: Basic Books. 